\title{
Role-playing: teaching strategy that encourages reflections on nursing care
}

\author{
Role-playing: estratégia de ensino que propicia reflexões sobre o cuidado de enfermagem \\ Role-playing: estrategia de enseñanza que propicia reflexiones sobre la atención de enfermeira
}

\section{Luciara Fabiane Sebold', Julia Estela Willrich Boell', Vivian Costa Fermo', Juliana Balbinot Reis Girondi', José Luís Guedes dos Santos'}

\author{
' Universidade Federal de Santa Catarina. Florianópolis, Santa Catarina, Brazil.
}

\begin{abstract}
How to cite this article:
Sebold LF, Boell JEW, Fermo VC, Girondi JBR, Santos JLG. Role-playing: teaching strategy that encourages reflections on nursing care. Rev Bras Enferm [Internet]. 2018;71(Suppl 6):2706-12. [Thematic Issue: Good practices

in the care process as the centrality of the Nursing]. DOI: http://dx.doi.org/10.1590/0034-7167-2017-0733
\end{abstract}

\section{Submission: 10-23-2017 Approval: 05-25-2018}

\section{ABSTRACT}

Objective: Describe the reflections of nursing students on nursing care through the use of role-playing. Method: Qualitative research with descriptive-exploratory approach and documentary base. The data were collected from portfolios of 32 students from an undergraduate course in the Southern Brazil. The analysis of the data followed the steps of sorting, classification in structures of relevance, synthesis and interpretation. Results: Two empirical categories were obtained: (1) Feelings in the act of taking care and receiving care and (2) Reversing roles: benefits to the nurse in the act of caring. Final considerations: The use of role-playing as a strategy for teaching the theme of care to undergraduate students encouraged reflections about the skills and abilities necessary for the act of taking care and favored the students' self-perception as nurses, appropriating the essence of their future profession: care. Descriptors: Education, Nursing; Problem-Based Learning; Professional Competence; Students, Nursing; Nursing Care.

\section{RESUMO}

Objetivo: Descrever as reflexões de estudantes de enfermagem sobre o cuidado de enfermagem a partir do uso do role-playing. Método: Pesquisa qualitativa com abordagem descritivo-exploratória e de base documental. Os dados foram coletados a partir dos portfólios de 32 alunos de um curso de graduação da região Sul. A análise dos dados seguiu as etapas de ordenação, classificação em estruturas de relevância, síntese e interpretação. Resultados: Obtiveram-se duas categorias empíricas: (1) Sentimentos no ato de cuidar e ser cuidado e (2) Invertendo papéis: benefícios para o ser enfermeiro no ato de cuidar. Considerações finais: $\mathrm{O}$ uso do role-playing como estratégia de ensino para alunos da graduação na temática do cuidado colaborou para despertar reflexões acerca das competências e habilidades necessárias para o ato de cuidar, como também para que os alunos pudessem se "perceber" como enfermeiros, apropriados da essência de sua futura profissão: o cuidado.

Descritores: Educação em Enfermagem; Aprendizagem Baseada em Problemas; Competência Profissional; Estudantes de Enfermagem; Cuidados de Enfermagem.

\section{RESUMEN}

Objetivo: Describir las reflexiones de estudiantes de enfermería sobre la atención de enfermería a partir del uso del role-playing. Método: Investigación cualitativa con enfoque descriptivo-exploratorio y de base documental. Los datos fueron recolectados a partir de los portafolios de 32 alumnos de un curso de graduación de la región Sur. El análisis de los datos siguió las etapas de ordenación, clasificación en estructuras de relevancia, síntesis e interpretación. Resultados: Se obtuvieron dos categorías empíricas: (1) Sentimientos en el acto de cuidar y ser cuidado; y (2) Inversión de papeles: beneficios en ser enfermero en el acto de atención. Consideraciones finales: El uso del role-playing como estrategia de enseñanza para alumnos de la graduación en la temática del cuidado colaboró para despertar reflexiones acerca de las competencias y de las habilidades necesarias para el acto de cuidar, así como para que los alumnos pudieran "percibirse" como enfermeros, apropiados de la esencia de su futura profesión: la atención. Descriptores: Educación en Enfermería; Aprendizaje Basado en Problemas; Competencia Profesional; Estudiantes de Enfermería; Atención de Enfermería. 


\section{INTRODUCTION}

The Brazilian National Curricular Guidelines for nursing highlight the importance of the formation of a critical, reflective, competent and skilled professional for the practice of health care aimed at transforming the Brazilian social reality ${ }^{(1)}$. Since the promulgation of the guidelines, the undergraduate courses in nursing have been making efforts in the structuring and implementation of educational projects that enable the fulfilment of the requirements exposed in the national curricular guidelines. This is an continuous process permeated by discussions about the particularities of nursing education and by appropriate teaching strategies to achieve the desired vocational training in the field, which develops according to changes in paradigms and in higher education trends.

In this context, one of the actions that have been valued by teachers and educational institutions is the adoption of active teaching-learning methodologies in the area of health ${ }^{(2)}$. The use of active methodologies contributes for overcoming the traditional education model, centered in the Cartesian paradigm, focused on strengthening the technical capacity without a teaching with transformative perspective, in which the teacher has the role of transmit the knowledge and the students have a passive attitude in which memorizing the content is the part of the latter, without reflection and/or critical understanding. Active methodologies seek to give the student power to manage his/her own formation process. For changing paradigms in the health and nursing education, the critical pedagogy and emancipatory education are relevant. Through it is possible to encourage the critical reflection and the collective and dialogic knowledge construction, based on integrating theory and practice from a concrete social reality ${ }^{(3)}$.

Among the active methodologies, role-playing appears as a strategy employed in teaching, for educational and ludic purposes, in which a coordinator elaborates a fictional situation in which students take on the role of other individuals and experience clinical situations that allow them to awaken the critical/reflective eye and to practice skills that make students suitable for their professional future, transforming the reality ${ }^{(4)}$. Therefore, it consists of a student-centered strategy supported by a reflection and guided by a facilitator ${ }^{(5)}$ that allows learning in a educational environment.

Role-playing can be used as a clinical low-fidelity simulation of type "standardized patient", as long as the principles of clinical simulation are followed. In this case, the experience and learning occur through other individuals; students or actors who are taught/instructed by the facilitator to portray the patient consistently according to the intended reality ${ }^{(6-7)}$. Studies that used role-playing as a teaching strategy highlighted its importance for the self-knowledge ${ }^{(8)}$, humanization of $\operatorname{care}^{(9)}$, enhancement of communication and other social interaction skills ${ }^{(10-11)}$, as well as the articulation of the theory to real situations of care ${ }^{(10)}$.

From the contributions of role-playing to nursing education described in the literature, the interest in using the strategy for discussing the meanings and practices related to nursing care with nursing students aroused. This focus of the study was chosen not only because of the centrality and importance of care as the central axis of the professional practice of nursing, but also due to the need for the development of attitudes and relational competencies for conducting a care beyond the instrumental dimension ${ }^{(12)}$.

\section{OBJECTIVE}

To describe the reflections of nursing students on nursing care through the use of role-playing.

\section{METHOD}

\section{Ethical aspects}

This study is part of a macro project entitled Active teaching methodologies in the vocational education in nursing: rethinking the strategies for the teaching-learning process in the undergraduate education, approved by the Committee of Ethics in Research of the Federal University of Santa Catarina. The subjects agreed to attend the research and signed the informed consent form (ICF), and their names were identified by alphanumeric symbols.

\section{Theoretical-methodological framework}

The theoretical-methodological framework of this study is based on assumptions of the critical pedagogy and emancipatory education, as well as on national and international studies about role-playing as a teaching strategy in nursing.

\section{Type of study}

Qualitative research with descriptive-exploratory approach and documentary base.

\section{Methodological procedures}

This study was carried out with 32 nursing students during a discipline entitled Grounds For Professional Care. This discipline is based on assumptions of the problematizing critical pedagogy and uses the role-playing as one of its teaching strategies. Within the discipline, role-playing was used in a class addressing the theme "care" in order to stimulate students" reflection on what is care and the way it occurs in nursing, in order to prepare them for the theoretical-practical activities in the hospital context.

A room with a wide and cozy space, with mattresses and audiovisual materials, was used as a physical resource. The group dynamic was developed in three steps:

1. When the students arrived at the room, they were encouraged to sit in circle on the mattresses. Listening to a soft music, they were asked to close their eyes and think about care situations, i.e. in which they took care of someone or received care. Duration: 10 minutes.

2. The students were divided into pairs and instructed about how the role-playing would be conducted for addressing hospitality and the relationship of trust between nurse and patient. First, the eyes of one of the students of the pair were blindfolded (representing the person to be cared for - patient), and his/her colleague was responsible for guiding her/him while exploring the environment outside the classroom (person conducting the care - nurse). In 
this context, it was proposed to students that the nurse would create a bond with the patient and discuss situations related to the patient's health condition. Then, the roles were reversed. Duration: 25 minutes.

3. The students were encouraged to evaluate their experience together with their colleagues, attending the process identified as debriefing. This step was guided by the teacher who accompanied the activity and encouraged students to reflect on the experience through open questions: How did they feel when playing the role of caregiver? How did they feel when playing the role of a person receiving care? What happened during the experience? What are the strengths and weaknesses identified during the act of taking care? At the end, the teacher summarized the information provided collectively by the group. Duration: 75 minutes.

\section{Study scenario}

This study was carried out in an undergraduate course in nursing from a public institution in the Southern Brazil.

\section{Data source}

The data were obtained from the reflective portfolios of 32 students addressing the experience described above. Thus, the number of participants was defined through the concept of saturation sampling, i.e. when all the eligible individuals are included in the study ${ }^{(13)}$. Portfolio is a document produced by students with their reflections about the didactic-pedagogical activities carried out in an academic discipline. Also, it allows monitoring the evolution of the student's teaching-learning process ${ }^{(14)}$.

\section{Data collection and organization}

The data were collected between March and June 2015, directly from the students' portfolios. The reports concerning the class about "care" were extracted from the portfolios, according to the three steps previously described. Fragments of these reports in which the students described the contributions of the role-playing strategy to nursing education were compiled into a Microsoft Word document, and the stage of analysis of data was performed.

\section{Analysis of the data}

The analysis of the data followed the steps of sorting, classification in structures of relevance, synthesis and interpretation. In the sorting step, a review of the material and a sorting of the reports were performed. In the step of classification of data, the structures of relevance were identified through an exhaustive and repetitive reading of the students' texts. In the final analysis, empirical and theoretical material were articulated for the interpretation of the facts ${ }^{(15)}$. Thus, the aim was to respond to the objective of the study adding similar information for the establishment of two empirical categories: (1) Feelings in the act of taking care and receiving care and (2) Reversing roles: benefits to the nurse in the act of caring.

\section{RESULTS}

The use of role-playing as a strategy for teaching the theme of care to undergraduate students encouraged reflections about the skills and abilities necessary for the act of taking care and favored the students' self-perception as nurses, appropriating the essence of their future profession: care. Hereinafter, the two categories of the study are shown.

\section{Feelings in the act of taking care and receiving care}

Through the use of the role-playing strategy, while playing the role of person receiving care, the students experienced different feelings faced with the unknown (in this case, the deprivation of sight in an environment to be recognized), as insecurity, powerlessness, apprehension and fear. Thus, they highlighted the importance of the presence of a caregiver as a guide in this difficult moment:

In fact, being deprived of sight and having to trust in the ability of someone else to guide me and take care of my physical integrity was very distressing. (Student 6)

I don't think I've ever felt as sick and fearful as during this activity. Being not able to see and understand what is being done causes so much insecurity and fear. (Student 20)

When I was still inside the room, already blindfolded, I felt insecure, afraid that my guide could be distracted for a few moments and, thus, I could end up injuring myself. (Student 14)

After going out for a walk, I was, at first, a little apprehensive with the shadows of the doors, windows etc., I felt like I was going to hit something, but I realized that my guide and, also, my new eyes was there, looking after me. (Student 14)

While playing the role of caregivers, the students expressed feelings of empathy, trust, security, respect and sensitivity when guiding their colleague:

When reversing the roles, I felt important while taking care of someone, I tried to transmit security and confidence to my colleague. I watched as the physical structure can be dangerous when the patient is not correctly oriented and assisted. (Student 14)

When we look after we need to have confidence in ourselves, trust that we are competent to carry out this work, and do it in a way that the person can be guided, that is, respect the "rhythm" and the gait pattern of this person. (Student 5)

After attending the role-playing strategy and experiencing a variety of feelings, the students related the experience to the reality of "being a nurse" and "being a patient":

That was a strong experience, in which we felt completely at the mercy of the other, insecure and powerless. During the dynamics, I put myself in the position of a patient under the care of a health professional, and I think that the patient's feelings must be close to what we experienced, a feeling of surrender and submission. (Student 11)

I really enjoyed this dynamic, because I realized how being conducted, trusting in someone is harder than guiding. It made us associate with the empathy for patients who will be cared for by us. (Student 2) 
We need to be sensitive and know how to feel what the patient is really wanting or feeling, to know to what extent we can approach and what must be dialogued. (Student 2)

While some of them reported having difficulties to guide their colleagues, others emphasized the confidence necessary to be conducted by someone. They attributed this fact to the relationship established between nurse and patient, in which the patient is in a susceptible situation and needs care and, thus, need to trust in the health professional:

For me, being guided was easier than guiding my colleague. As I already knew her, I felt safe and confident to take the steps in the dark. Guiding was harder, because of the responsibility assumed over the body of the other. (Student 22)

In the first part of the class, the dynamic of trust was the most remarkable thing. I felt safe while guiding my colleague who was blindfolded, but when I was guided by her I was afraid of falling or hitting something. (Student 2)

My colleague was blindfolded, and my task was to guide her through the corridors. She was a little nervous and scared, but she gradually started walking more calmly. In the second part, the roles were reversed; I was blindfolded and she would guide me. I walked quietly through the corridors. (Student 7)

\section{Reversing roles: benefits to the nurse in the act of caring}

The experience allowed them to reflect on various aspects of care, such as the best practices to adopt as a caregiver, using the knowledge, skills and attitudes necessary for their performance as future nurses. In this way, the dynamics used was positively evaluated by the participants:

The class interactivity facilitated my understanding about what is the nursing care and its importance for the patient's recovery. (Student 1)

The teachers try to work as close to reality as possible. (Student 2)

Debriefing became easier for the students to associate the activity with their future professional practice. Moreover, the aforementioned perceptions enumerated challenges of being guided and guide, that is, of taking care and receiving care, so that the simulation provided several experiences and learnings among the participants, as follows:

When we are being cared for, sometimes we do not know what is happening and what will happen, but someone is guiding us, and this person has to make as feel confident about what is being made. (Student 26)

The activity showed the importance of knowing how to guide a patient when needed, and how he/she can feel uncomfortable and insecure, just like we did during the dynamic. That is why we must act with caution and know how to transmit confidence to the patient. (Student 23)

The students reported that putting themselves in the position of the patient allowed them to think about what is care and identify skills that will be required for their future professional practice. Considering that, reflecting on what type of professional the student wants to be in the future was possible:

it made me reflect about what is "care" [...] and the first thing that came into my mind was patience [...], something to be strongly exercised, because, constantly, we will deal with different people and their beliefs, ideas and opinions, which must be respected. (Student 1)

It made me think about the importance of putting ourselves in the position of the other, about how hard it is to be cared for without knowing what the other is doing with you, as well as about the importance of explaining the procedures to the patient in a simplified way so that he/she can feel more confident. (Student 5)

We need to have sensitivity to the others, empathy, solidarity, unity and respect. (Student 7)

For me, the main objective of this activity was to realize that the perspective on care differs from person to person, but that all points of views must be considered as long as they are somehow related to care. (Student 9)

It made me think about what kind of nurse I will be and how I will react to different situations within the hospital. (Student 20)

Through the exercise performed, the need for providing a safe environment and detailed orientations to the patient during the whole care process was also evident among the students. This is important because the patients are in a unknown place, going through procedures that often are not part of their everyday life:

Relocating this reflection of the dynamic to the hospital context, you must consider that the patient does not know what will be done or what is going to happen to him, that is why clarifying and dispelling their doubts is important. (Student 27)

I hope I always remember in my professional performance that the patient is "blind". He/She does not understand much of what is being done, what is going on, and, as a nurse, I should always explain the procedures, talk, make the patient aware of the situation. (Student 20)

\section{DISCUSSION}

The role-playing dynamic was incorporated and interpreted by the participants and showed some skills and actions related to the care for the other could be discovered and exercised inside each of the students through the role reversal proposed in the activity. The skills and actions observed were addressed in group for constructing a collective learning, which was interpreted individually by each participant. Feelings that led to learning acquisition were highlighted. The study ${ }^{(16)}$ with 228 nursing students, aiming at comparing the traditional pedagogy with the role-playing has shown the learning strategy is effective and attractive. In addition, it contributes to the group work 
and allows the exchange of knowledge between the individuals involved, enhancing the teaching-learning process.

Experiencing everyday hospital environment situations similar to those of the patients, through simulation, may be a rehearsal without risks of injury, encourages reflections and provides real changes in the nursing actions. Clearing more sensitive ways to teach and care mobilizes students to extend the discussions about care and about feeling the care, in order to deconstruct the idea that only the disease and the rationality is relevant when teaching, allows creating the idea that teaching via sensitivity and subjectivity matters because it produces skills and actions based on theoretical foundations aimed at studying care as an epistemic space to feel experiences by being a patient, including theoretical assumptions about body, care, feelings and environment ${ }^{(17)}$. Thus, the legacy of the exclusive valorization of the scientific rationality is minimized to the student - that is, a sign and symptom of disease and what makes them develop diversified forms of living the profession - through the learning of skills and actions promoting the act of caring.

The issues of this study evidenced that the use of this strategy promotes the internalization of values and behaviors in the future professionals $s^{(9)}$, improves and develops their learning, stimulating the interpersonal relationship in the group ${ }^{(16,18)}$. When addressing the phenomenon of care through a holistic teaching method, it was possible to promote critical/reflective thinking, instigate emotions and enable the construction of skills, knowledge and attitudes closer to the reality.

Similarly, the report of the experience of a group of teachers regarding the adoption of role-playing as a teaching strategy of nursing care for hospitalized adult patients stressed the potential of the technique for the development of skills for integral care. The authors point out that the circumstances staged instigate learning and bring the theory closer to the real care situations, as well as the students show good acceptance and feel valued, motivated, and active in the learning process ${ }^{(10)}$.

Another result evidenced in this research was that learning social skills favors the nurse-patient relationship and contributes to the establishment of bond and trust. Studies ${ }^{(19-20)}$ have shown that nurses' social skills, such as warmth, kindness, empathy and good communication, both in the professional-patient relationship and between the members of the professional team, are associated with the quality of the care and the satisfaction of those who receive it.

The science of care focuses on the interaction between the nurse and the person in need of care, and sometimes this interaction occurs in an environment that is unknown by the patient, with an asymmetry in the relation that places the patient in a situation of vulnerability. Under these conditions, the way care is employed has multiple consequences and, thus, may cause a set of sensations and emotions, directly associated with the patient's satisfaction level ${ }^{(21)}$.

An undergraduate course in medicine, by using the role-playing technique, showed, similar to this study, the importance of the patient's trust in the professional, as well as the need for explaining step by step what is being done and narrating the actions taken. Thus, the patient is aware of what is happening outside his/her visual field, and respect must be present throughout the process ${ }^{(9)}$. Since the technique promotes an environment in which the student is awakened to the empathy for the other and empowered with confidence to use care approaches, when he/she is faced with similar situations, it becomes clear that, among its particularities, it contributes to the safety of the patient and the student ${ }^{(22)}$.

The assimilation of the experience allowed by role-playing occurs during the debriefing, which offers to students the opportunity to reflect on the experience. The facilitator should structure the technique through questions (open questions) that optimize the development and promote the reflection of the students ${ }^{(23)}$. The debriefing with an appropriate judgment is based on open sharing of personal opinion and point of view. Considering this, the participants must respect one another, so that all of them can feel valued and capable and see this environment as an opportunity to discuss mistakes to avoid them in the future and acquire knowledge for strengthening a safe and good care. The facilitator is responsible for showing his/her experience and make constructive criticism to promote meaningful learning for students ${ }^{(24)}$. This is the moment in which revealing the mechanisms of thought through which understanding the reasons for the way the actions were performed is possible and thus students can improve their clinical performance as future nurses ${ }^{(25)}$

Health professionals, by realizing a reality, rationally integrate all data present in the case presented, so that their active thought process allows them to filter, infer, interpret and give meaning to the experience. The analysis of clinical results focused only on the actions may be ineffective, because it does not allow to understand the reasons why one acted in a certain way. That is, it is important that the student express the cause or mental models that generated a clinical performance to enhance learning and discuss improvements to be made. In this way, developing a lasting knowledge for future professional performances is possible ${ }^{(25)}$.

Once the facilitator is the responsible for organizing a roleplaying having a debriefing based on an adequate judgement, the continuous update of these processes is recommended, motivating her/him to rethink and discuss the pedagogical practices, and developing follow-up studies and evaluation of strategies for teaching and learning ${ }^{(10)}$.

\section{Limitations of the study}

The fact that this study was carried out in a single scenario is regarded as a limitation, because generalizations about the results shown must be made by considering the particularities of each context. In addition, choosing to use the documentary analysis through the students' portfolios has limited the possibilities for exploring and/or deepening other nuances of the issue in question.

Contributions to the field of nursing, health or public policies The results shown will favor the use of active methodologies in the nursing education, especially of role-playing. Also, further studies exploring, for instance, the perspective of teachers who use role-playing as a learning strategy in nursing are required.

\section{FINAL CONSIDERATIONS}

The role-playing strategy facilitates the pedagogical dynamic when it comes to nursing education, addressing the relation of trust and care, and showing that putting oneself in the position of the other is a complex task that requires training. Through the 
technique, awakening the empathy regarding the nursing care was possible. When putting themselves in the position of the other, the students were able to show the importance of the way the care needs to happen and how he/she, the student, would like to receive this care as a patient, contributing, thus, to the humanization of nursing care. In addition, the use of role-playing enables a greater interaction between the participants, contributing to the development of the skills and attitudes necessary for group work.

\section{REFERENCES}

1. Brasil. Conselho Nacional de Educação. Câmara de Educação Superior. Resolução CNE/CES No 3 de 7 de novembro de 2001. 139p. Institui Diretrizes Curriculares Nacionais do Curso de Graduação em Enfermagem. Brasília, 2001.

2. Carácio FCC, Conterno LO, Oliveira MAC, Oliveira ACH, Marin MJS, Braccialli LAD. A experiência de uma instituição pública na formação do profissional de saúde para atuação em atenção primária. Ciênc Saúde Colet[Internet]. 2014 [cited 2017 Oct 21];19(7):2133-42. Available from: http://www.scielo.br/pdf/csc/v19n7/1413-8123-csc-19-07-02133.pdf

3. Canever BP, Prado ML, Gomes DC, Jesus BH, Backes VMS. Naive world awareness in the pedagogical practice of healthcare professors. Texto Contexto Enferm[Internet]. 2017[cited 2017 Aug 24];26(2):e3340015. Available from: http://www.scielo.br/pdf/ tce/v26n2/0104-0707-tce-26-02-e3340015.pdf

4. Kalinowski CE, Massoquetti RMD, Peres AM, Larocca LM, Cunha ICK, Gonçalves LS, et al. Metodologias participativas no ensino da administração em Enfermagem. Interface Comun Saúde Educ[Internet]. 2013[cited 2017 Jun 06];17(47):959-67. Available from: http://www.scielo.br/pdf/icse/v17n47/aop4413.pdf

5. Oliveira SN, Prado ML, Kempfer SS. Use of simulations in nursing education: an integrative review. Rev Min Enferm[Internet]. 2014[cited 2017 Jun 08];18(2):496-504. Available from: http://www.reme.org.br/artigo/detalhes/941

6. Kinney S, Henderson D. Comparison of low fidelity simulation learning strategy with traditional lecture. Clin Simulat Nurs[Internet]. 2008[cited 2017 Jun 09];4(2):e15-e18. Available from: http://www.nursingsimulation.org/article/S1876-1399(08)00006-6/pdf

7. Decker S, Sportsman S, Puetz L, Billings L. The evolution of simulation and its contribution to competency. J Contin Educ Nurs[Internet]. 2008[cited 2017 Jun 09];39(2):78-80. Available from: https://www.ncbi.nlm.nih.gov/pubmed/18323144

8. Souza VB, Orti NP, Bolsoni-Silva AT. Role-playing como estratégia facilitadora da análise funcional em contexto clínico. Rev Bras Ter Comp Cogn[Internet]. 2012[cited 2017 May 09];XIV(3):102-22. Available from: http://pepsic.bvsalud.org/pdf/rbtcc/v14n3/ v14n3a06.pdf

9. Aragão JCS, Silveira CO, Hungria MM, Oliveira MP. O uso da técnica de role-playing como sensibilização dos alunos de Medicina para o exame ginecológico. Rev Bras Educ Med[Internet]. 2009[cited 2017 Oct 21];33(1):80-3. Available from: http://www.scielo. $\mathrm{br} / \mathrm{pdf} / \mathrm{rbem} / \mathrm{v} 33 \mathrm{n} 1 / 11 . \mathrm{pdf}$

10. Cogo ALP, Dal Pai D, Aliti GB, Hoefel HK, Azzolin KO, Busin L, et al. Case studies and role play: learning strategies in nursing. Rev Bras Enferm[Internet]. 2016[cited 2017 Sep 12];69(6):1231-5. Available from: http://www.scielo.br/pdf/reben/v69n6/en_00347167-reben-69-06-1231.pdf

11. Yu M, Kang KJ. Effectiveness of a role-play simulation program involving the sbar technique: a quasi-experimental study. Nurse Educ Today[Internet]. 2017[cited 2017 Sep 12];53:41-7. Available from: https://www.ncbi.nlm.nih.gov/pubmed/28433731

12. Queirós PJP, Fonseca EPAM, Mariz MAD, Chaves MCRF, Cantarino SG. Significados atribuídos ao conceito de cuidar. Rev Enferm Ref[Internet]. 2016[cited 2017 Sep 16];SerlV(10):85-94. Available from: http://www.scielo.mec.pt/pdf/ref/vserlVn10/serlVn10a10.pdf

13. Fontanella BJB, Luchesi BM, Saidel MGB, Ricas J, Turato ER, Melo DG. Amostragem em pesquisas qualitativas: proposta de procedimentos para constatar saturação teórica. Cad Saúde Pública[Internet]. 2011[cited 2017 Aug 24];27(2):388-94. Available from: http://www.scielo.br/pdf/csp/v27n2/20.pdf

14. Forte M, Souza WL, Silva RF, Prado AF. Portfólio Reflexivo Eletrônico: resultados de um Projeto Piloto. Rev Bras Educ Méd[Internet]. 2016[cited 2017 Aug 24];40(2):234-44. Available from: http://www.scielo.br/pdf/rbem/v40n2/1981-5271-rbem-40-2-0234.pdf

15. Minayo MCS. O desafio do conhecimento: pesquisa qualitativa em saúde. $11^{\text {a }}$ ed. São Paulo: Hucitec; 2010.

16. Vizeshfar F, Dehghanrad F, Magharei M, Sobhani SMJ. Effects of applying role playing approach on nursing students' education. Int J Human Cult Stud[Internet]. 2016[cited 2017 Oct 21];(Spec-I):1772-81. Available from: https://www.ijhcs.com/index.php/ijhcs/ article/view/2445/2240

17. Figueiredo NMA, Tonini T, Santos I, Handem PC, Lopes LRF. Cuidado de enfermagem: espaço epistêmico de vivências de ensino a partir do ser cliente. Rev Enferm UERJ[Internet]. 2012[cited 2017 Oct 21];20(2):167-72. Available from: http://www.e-publicacoes. uerj.br/index.php/enfermagemuerj/article/view/4032/2786

18. Warland J, Smith M. Using online roleplay in undergraduate midwifery education: a case-study. Nurse Educ Pract[Internet]. 2012[cited 2017 Oct 21];12(5):279-83. Available from: https://www.ncbi.nlm.nih.gov/pubmed/22818037

19. Sánchez ZL, Pimenta CAM, Soto MTU. Competencias blandas y calidez en enfermería: definiciones, concepción y características. Horiz Enferm[Internet]. 2013[cited 2017 Oct 21];24(1):32-41. Available from: http://dx.doi.org/10.7764/Horiz_Enferm.24.1.32 
20. Van der Elst E, Dierckx-de-Casterlé B, Gastmans C. Elderly patients' and residents' perceptions of 'the good nurse': a literature review. J Med Ethics[Internet]. 2012[cited 2017 Oct 21];38(2):93-7. Available from: https://www.ncbi.nlm.nih.gov/pubmed/22038560

21. Rodríguez LM. Teorías de cuidado de la disciplina de enfermería. Aquichan[Internet]. 2012[cited 2017 Out 21];12(3):211-2. Available from: http://www.redalyc.org/articulo.oa?id = 74124948001

22. Fossen P, Stoeckel PR. Nursing students' perceptions of a hearing voices simulation and role-play: preparation for mental health clinical practice. J Nurs Educ[Internet]. 2016[cited 2017 Oct 21];55(4):203-8. Available from: https://www.ncbi.nlm.nih.gov/ pubmed/27023889

23. Husebo SE, Dieckmann P, Rystedt H, Soreide E, Friberg F. The relationship between facilitators' questions and the level of reflection in postsimulation debriefing. Simul Healthc[Internet]. 2013[cited 2017 Oct 21];8(3):135-42. Available from: https://www.ncbi. nlm.nih.gov/pubmed/23343839

24. Gardner R. Introduction to debriefing. Semin Perinatol[Internet]. 2013[cited 2017 Oct 21];37:166-4. Available from: https://www. ncbi.nlm.nih.gov/pubmed/23721773

25. Maestre JM, Rudolph JW. Theories and styles of debriefing: the good judgment method as a tool for formative assessment in healthcare. Rev Esp Cardiol[Internet]. 2015[cited 2017 Oct 21];68(4):282-5. Available from: http://www.revespcardiol.org/en/ theories-and-styles-of-debriefing/articulo/90398661/ 